\title{
RESULTS OF USING ENDOVASCULAR TECHNOLOGIES FOR REMOVAL OF CRITICAL LOWER LIMB ISCHEMIA IN PATIENTS OF REGIONAL VASCULAR CENTRES LOCATED AT MULTIDISCIPLINARY HOSPITALS
}

\author{
Artyushin B.S. ${ }^{1,2}$, Movchan K.N. ${ }^{2,3}$, Sukhov V.K. ${ }^{1,3}$, Shlojdo E.A. ${ }^{1}$, Shlomin V.V. ${ }^{1,3}$ \\ ${ }^{1}$ Saint Petersburg City multidisciplinary hospital No. 2, Saint Petersburg, e-mail: artyushin_boris@mail.ru; \\ ${ }^{2}$ Saint Petersburg Medical Information and Analytical Center, Saint Petersburg, e-mail: movchank@miac.zdrav.spb.ru; \\ ${ }^{3}$ North-Western State Medical University named after I.I. Mechnikov, Saint Petersburg, e-mail: suhov_vk@mail.ru
}

Aims.

The aim of the study was to evaluate the outcomes of health care in the setting of a regional vascular centre of a multidisciplinary hospital in patients with critical lower limb ischemia based on the data of preoperative arterial hypertension of the leg circulatory bed.

Materials and methods.

General data on the organisational effectiveness of regional vascular centres in the second largest Russian city, Saint Petersburg, were analysed. The work of a large multidisciplinary medical organisation of the city, City Multidisciplinary Hospital No. 2, was studied in detail, whose regional vascular centre examined and treated 295 men and 88 women with pathology of the lower limb arteries in 2013-2015. The patients underwent the following surgeries: open vascular reconstruction - 282, endovascular revascularisation - 47, and hybrid surgical interventions were performed in 15 patients. In 55 cases, lower limb revascularisation was refused due to lack of opportunities for vascular bed reconstruction or because of irreversible changes in the tissues of the lower limbs.

Results.

Application of the options of lower limb artery angiography preoperatively allowed to reliably estimate the degree of damage to the vascular bed, and make a reasoned choice between leg artery revascularisation methods. This technique proved to be most effective in patients with critical lower limb ischemia with severe comorbidity. Overall, the incidence of complications of open surgical interventions in vascular bed in the early postoperative period was $21.6 \%$, and of endovascular and hybrid surgeries - 15\% and $13.3 \%$, respectively. No cases of deaths were reported.

Conclusions.

Endovascular and hybrid surgical interventions in obliterating diseases of the lower limb arteries provides a significant reduction in the incidence of intra- and postoperative complications in patients with multifocal atherosclerosis, and their combination with the use of less traumatic "open" surgical interventions (semiclosed loop endarterectomy) offers new opportunities in the therapy of patients with critical lower limb ischemia.

Keywords: regional vascular centre, atherosclerosis, lower limb ischemia, angiography, revascularisation.

\section{INTRODUCTION.}

Circulatory pathologies have the highest incidence in Russian adults [1]. Finding ways to improve healthcare for cardiovascular patients is a key research area of today's medicine. One such way is to create new and improve the existing regional vascular centers [2]. Atherosclerotic changes in lower-limb arteries cause most of the critical ischemia cases [3]. Atherosclerosis is usually associated with multifocal and multilevel damage to the vascular bed [4]. In this regard, introducing methods for visualizing the lumen of lower-limb arteries has a special role to play in vascular surgery. Direct angiography (AG), magnetic resonance imaging, and computed tomography run in vascular mode are considered the golden standard for such diagnosis [5]. Preoperative AG helps not only find the extent, to which the lower-limb arterial bed has been affected, or plan the surgery, but also monitor the intraoperative and postoperative outcomes [6]. These technologies are important for endovascular or hybrid surgery of general vascular pathologies, in particular, those complicated by critical lower-limb ischemia [3]. However, research data on the use of angiography in such cases remains ambiguous.

The goal hereof was to evaluate the healthcare provided to critical lower-limb ischemia patients at regional vascular centers of multiprofile inpatient hospitals; the analysis drew into 
consideration the preoperative AG of the arterial bed in lower limbs.

MATERIALS AND METHODS. The research team studied medical statistics provided by the St. Petersburg Regional Vascular Center that examined and treated patients with cardiovascular surgical pathologies. To that end, the team analyzed the official databases of the St. Petersburg Health Information and Analysis Center collected over 2011-2016 and further analyzed the healthcare provided to patients examined and treated for critical lower-limb ischemia at one of the city's multiprofile inpatient hospitals, namely the City Multiprofile Hospital No. 2 (CMH2), which hosts the Regional Vascular Center and examined and treated 295 men and 88 women over 20132015. Twenty cases were related to bilateral lower-limb ischemia. Patients had to be hospitalized for a total of 403 times. Preoperative treatment used specific methods to visualize the vascular bed: direct angiography, computed tomography or magnetic resonance imaging in the vascular mode. Emphasis was made on the preoperative assessment of lower-limb arteries in patients that had earlier undergone reconstructive surgeries of such arteries. Patients underwent open, endovascular, or hybrid surgery depending on the degree and length of occlusion. Comprehensive conservative treatment was provided where the lower-limb tissues could not be revascularized.

Microsoft Excel was used for statistical data processing.

The study protocol followed guidelines for experimental investigation with human subjects in accordance with the Declaration of Helsinki and was approved by the ethics committee. Written informed consent was obtained from each patient (or an official representative) before the study.

RESULTS. According to healthcare statistics, every year nearly a thousand people are killed by circulatory system diseases for every 100,000 inhabitants of St. Petersburg. Acute myocardial infarction (AMI) accounts for most fatalities. The St. Petersburg Region registers $~ 10 \mathrm{k}$ new AMI cases per annum or 30 a day.

Since 2002, St. Petersburg has had measures in place to establish regional vascular centers to provide specialized healthcare for patients with circulatory system diseases. These measures helped establish a state-of-the-art healthcare system for patients with cardiovascular pathologies, which did improve the urgent medical care available to AMI and CVA patients. In particular, the incidence of circulatory system diseases has declined since 2009 (440.95 per 1,000 inhabitants, cf. 454.93 in 2008). The incidence continued to decline to 439.98 in 2010, 406.4 in 2011. The new program for better circulatory care that St. Petersburg had in place under the Federal Program of 2002-2010 continued in 2011 and 2012. In 2011, St. Petersburg established regional vascular centers at: St. Petersburg Dzhanelidze Research Institute of Emergency Medicine, City Hospital No. 26, City Mariinskaya Hospital, City Pokrovskaya Hospital, City Yelizavetinskaya Hospital, and City Aleksandrovskaya Hospital. As of early 2011, the Regional Vascular Centers had 907 beds. This year alone, the Centers helped 21,171 patients. The fatality rate was $10 \%$ or 2,125 cases. While the number of beds varied within 895 to 1,123 , ever more patients were hospitalized with every passing year: 24,291 in 2012, 24,710 in 2013, 23,980 in 2014, and 29,016 in 2015. 
The fatality rates stalled at $10.4 \%$ to $12.0 \%$. Since 2012 , the city has had primary vascular units in place. By 2015, they had attained 319 beds and had provided specialized healthcare to 22,696 patients over four years with 1,550 fatal cases (6.8\%). In 2016, St. Petersburg opened more Regional Vascular Centers at the Almazov National Medical Research Center, as well as at the primary vascular unit of $\mathrm{CMH} 2$. The eight regional centers with their 1,294 beds provided specialized care to 35,367 patients with a hospital fatality rate of $8.1 \%$ or 2,888 cases. Six primary vascular units treated 4,988 patients.

Apparently, the Regional Vascular Centers and primary vascular units rose in size from 907 to 1,493 beds over the studied period, while the total yearly patient counts rose from 21,171 to 40,355 cases, i.e. doubled; at the same time, the fatality rate dropped from 10 to $6.8 \%$.

Since 2012, CMH2 has also had five primary vascular units and an X-ray surgery diagnosis and treatment unit, transformed in 2016 into a Regional Vascular Center. Over 5 years, the Regional Vascular Center of CMH2 treated 21,814 patients. The fatality rate ranged from $3.5 \%$ to $4.7 \%$, i.e. was way below the city's average, see Table 1; this was what motivated the research team to specifically focus on this hospital and its records.

Table 1.

Cardiology-related performance indicators of the Regional Vascular Center of the City Multiprofile Hospital No. 2, 2012 to 2016.

\begin{tabular}{|l|r|r|r|r|r|}
\hline \multirow{2}{*}{ Operating indicators } & \multicolumn{5}{|c|}{ Value for } \\
\cline { 2 - 6 } & \multicolumn{1}{|c|}{2012} & 2013 & 2014 & 2015 & \multicolumn{1}{c|}{2016} \\
\hline beds & 200 & 200 & 200 & 185 & 150 \\
patients hospitalized & 4,115 & 3,881 & 4,042 & 4,297 & 5,479 \\
of them deceased & 148 & 162 & 163 & 158 & 260 \\
deaths within 24 hours of & 27 & 24 & 28 & 38 & 59 \\
hospitalization & & & & & \\
total bed days & 54,592 & 52,199 & 51,110 & 48,332 & 56,575 \\
\hline
\end{tabular}


Regional Vascular Centers prioritize healthcare for patients with acute myocardial infarction and cerebrovascular accidents (CVA). However, most outpatient hospitals of the city currently have specialized vascular surgery units that treat peripheral artery diseases, including in terminal stages. Today's surgery tends to actively use the endovascular approach to treat critical lower-limb ischemia. This requires specialized X-ray enabled or hybrid operating theaters. As a rule, an inpatient hospital only has one or two X-ray enabled theaters, and peripheral artery diseases are not a priority there.

Despite some difficulties, MHT2's success in the treatment of critical lower-limb ischemia proves the diagnosis and treatment process could well be optimized if approached appropriately.

MHT2 performed 171 direct angiography tests, 150 vascular-mode MRI and CT tests before operating on such patients. All the patients were found to have elongated TASC-2 Type C and Type D [6] atherosclerotic lesions in the aortoiliac and/or femoropopliteal segments.

Pursuant to the National Guidelines on the Treatment of Lower-Limb Artery Diseases [5], MHT2 prioritized open revascularization. Endovascular treatment was mainly reserved for elderly and senile patients with pronounced comorbidities. Hybrid surgeries were performed in the case of multilevel vascular affliction. These patients also underwent semi-closed loop endarterectomy from the aortoiliac and femoropopliteal segments of the lower limbs.

Two hundred thirty-eight patients received surgery on lower-limb arteries, of whom 16 also had revascularizations over the next three years to treat critical leg ischemia, while 2 had to have their contralateral lower limb amputated. In total, the clinic performed 282 open surgeries, 47 endovascular surgeries, and 15 hybrid ones, see Table 2. Fifty-nine patients were found to lack substrate for revascularization, for which reason 14 of them underwent lumbar sympathectomy, 30 were treated conservatively. Primary amputation of the lower limb was performed in 15 patients: 11 transfemoral disarticulations and 4 transtibial ones.

Table 2

Surgical interventions to treat critical ischemia of the lower limbs,

MHT2, 2013-2015

\begin{tabular}{|c|c|}
\hline Surgeries & $\begin{array}{c}\text { Number of } \\
\text { cases }\end{array}$ \\
\hline open surgery of segments & 282 \\
\hline aortoiliac & 72 \\
\hline femoropopliteal & 152 \\
\hline two-level reconstructions & 32 \\
\hline various kinds of thromboendarterectomy & 17 \\
\hline repeated surgery & 6 \\
\hline simultaneous surgery & 1 \\
\hline sundry surgery & 2 \\
\hline endovascular surgery of segments: & 47 \\
\hline aortoiliac & 6 \\
\hline femoropopliteal & 37 \\
\hline two-level reconstructions & 4 \\
\hline
\end{tabular}


endovascular correction of the aortoiliac segment + open reconstruction

of the femoropopliteal segment

+ endovascular recanalization of the distal bed

open revascularization of the aortoiliac segment + endovascular

correction of the femoropopliteal segment

open revascularization of the femoropopliteal segment +

endovascular correction of the distal bed

Surgeries total

Open revascularization of the aortoiliac segment was performed in 72 cases, surgical reconstruction of the femoropopliteal-tibial segment was performed in 152 cases, while 32 patients had two-level reconstructions. Twenty-six patients had various kinds of thromboendarterectomy and repeated surgery. Semi-closed loop endarterectomy was the most common surgery (190 cases). Forty-five patients had a bypass, 17 patients had various kinds of thromboendarterectomy, and 9 had non-standard reconstructive surgery of previously operated vessels. Endovascular surgery was performed in 47 cases: 6 in the aortoiliac segment, 37 in the femoropopliteal-tibial segment, and 4 two-level revascularizations. Eighteen patients underwent stenting, 29 had balloon angioplasty, 15 had hybrid surgery.

The inflow and outflow beds were corrected: the lumen of the aortoiliac segment was restored endovascularly in 10 cases, using a Vollmar loop in 2 cases; open femoral endarterectomy was performed in 3 cases. The distal bed was corrected openly in some cases and endovascularly in others.

Open surgery did yield positive results of treating the critical lower-limb ischemia in 221 cases. Postoperative complications were observed in 61 cases $(21.6 \%)$ with a total of 74 adverse effects of surgery. Thirty-two patients' complications pertained to the specifics of surgery in the vascular bed reconstruction zones: 21 thromboses and 2 anastomosis bleeding cases. Twelve patients had insufficient blood flow despite the reconstruction zone being passable. Complicationaddressing surgeries were performed for 42 patients. In 30 cases, the surgeons managed to avoid lower-limb amputation, while 12 patients had to undergo secondary amputation ( 8 transfemoral disarticulations and 4 transtibial ones).

The endovascular approach successfully restored the blood flow in the lower-limb arteries in 40 cases, the hybrid approach did in 13 cases. Seven patients (15\%) had endovascular complications, and 2 (13.3\%) had hybrid ones. Complications totaled 15 and 2 cases, respectively, in both groups. Two followed-up endovascularly treated patients had thrombosis of the angioplasty zone and lower-limb artery stenting; inadequate perfusion despite a passable vascular bed was detected once in both groups. Vascular reconstruction zone bleeding and postoperative wound lymphorrhea complicated the early postoperative period in one endovascularly treated patient and one hybrid-treated patient. Complication-addressing surgeries were performed for 8 patients and for 1 patient, respectively. In three cases, endovascular treatment failed to preserve the lower limb, 
resulting in 2 transfemoral disarticulations and one transtibial disarticulation.

No fatalities were observed.

The data suggests St. Petersburg's Regional Vascular Center Program is a success. It means there is well-grounded hope the positive trends in cardiovascular care will be solidified. It is therefore strongly advisable to keep and further improve this approach to healthcare.

CONCLUSIONS. Preoperative angiography of lower-limb arteries can adequately and reliably assess the degree to which the vascular bed has been affected so as to properly choose a specific arterial revascularization method. This is especially important in critical lower-limb ischemia patients with pronounced comorbidities. Endovascular and hybrid surgery addressing the obliterative lower-limb artery diseases dramatically reduces the incidence of intra- and postoperative complications in multifocal atherosclerosis patients; combining them with less traumatic open surgery (semi-closed loop endarterectomy) opens up new opportunities in the treatment of critical LL ischemia.

FINANCIAL SUPPORT AND SPONSORSHIP

Nil.

\section{CONFLICTS OF INTEREST}

The authors declare no conflict of interest

\section{SUPPLEMENTARY DATA (DOI)}

\section{REFERENCES}

1. Shal'nova S.A. Epidemiologiia serdechno-sosudistykh zabolevanii i faktory riska $\mathrm{v}$ Rossii [Epidemiology of cardiovascular diseases and risk factors in Russia]. Kardiologiia: natsional'noe rukovodstvo [Cardiology: national guide]. Moscow, GEOTAR-Media, 2010, pp. 37-52..

2. Reznikova I.S., Movchan K.N., Artiushin B.S. The possibilities of decreasing the frequency of deaths in cases of blood circulatory system diseases in saint petersburg medical centres by creation of the regional vascular centers [Vozmozhnosti snizheniia chastoty sluchaev smertel'nykh iskhodov v meditsinskikh uchrezhdeniiakh Sankt-Peterburga pri zabolevaniiakh sistemy krovoobrashcheniia putem sozdaniia regional'nykh sosudistykh tsentrov ]. Fundamental research - Fundamental'nye issledovaniia, 2013, no. 9, pp. 460-467.

3. Koidan, A. A. Batalin I. V., Vavilov V. N. et al. Comparative results of different methods of arterial reconstruction in the patients with critical stenosis of the femoral-popliteal-tibial segment [Sravnitel'nye rezul'taty razlichnykh metodik arterial'noi rekonstruktsii pri porazhenii bedrennopodkolenno- bertsovogo segmenta u bol'nykh s khronicheskoi kriticheskoi ishemiei nizhnikh konechnostei]. Regional blood circulation and microcirculation - Regionarnoe krovoobrasenie $i$ mikrocirkulacia, 2017, vol. 16, no 3, pp. 41-48, doi 10.24884/1682-6655-2017-16-3-41-48.

4. Ed by Savel'ev V.S., Kirienko A.I. Vascular surgery. National guide. Short edition [Sosudistaia khirurgiia. Natsional'noe rukovodstvo. Kratkoe izdanie]. Moscow, GEOTAR-Media, 2014, 464 p. 
5. National Recommendations for Management of Patients with Lower Limb Artery Diseases (Russian Conciliation Document) [Natsional'nye rekomendatsii po vedeniiu patsientov $\mathrm{s}$ zabolevaniiami arterii nizhnikh konechnostei (Rossiiskii soglasitel'nyi dokument)], Moscow, 2013, $70 \mathrm{p}$.

6. TASC Working Group Inter-Society Consensus for the Management of Peripheral Arteria disease. European Journal of Vascular and Endovascular Surgery, 2007, vol. 33, Suppl. 1, pp S.5-67. 